\title{
MODELING RELATIONSHIP BETWEEN COGNITIVE ABILITIES AND ECONOMIC ACHIEVEMENTS
}

\author{
S.G. KULIVETS ${ }^{\mathrm{a}}$, D.V. USHAKOV
}

\begin{abstract}
${ }^{a}$ V.A. Trapeznikov Institute of Control Sciences of the Russian Academy of Sciences, 65 Profsoyuznaya str., Moscow, 117997, Russian Federation

${ }^{b}$ Institute of Psychology of Russian Academy of Sciences, 13 build. 1, Yaroslavskaya str., Moscow, 129366, Russian Federation
\end{abstract}

\begin{abstract}
Both economists and psychologists proved the role of cognitive abilities and competencies in economic achievements. The assumption that more capable and educated individuals achieve better economic results underlies most of these researches. This assumption is evidently true as a general tendency, but it cannot explain modest economic achievements in certain countries with high levels of human capital development. We propose that problem solving is the mediator between human competencies and achievements. Creation of goods and services is based on problem solving in design, production and delivery. The quality of problem solving depends on human competencies and, in turn, determines economic achievements. More importantly, the choice of problems to be solved creates or does not create the possibility for application of highly qualified labor and, as a result, for full-fledged realization of human capital. We propose a mathematical model based on these assumptions. The simulation reproduces most important traits of Lynn and Vanhanen's (2002) findings. The simulation shows a non-linear growth of economic achievements with national IQ growth as well as an increase of between countries variance. Thereby the proposed model can serve as a satisfactory explanation for empirical data on links between national IQs and economic achievements.
\end{abstract}

Keywords: intelligence, competence, human capital, GDP, problem solving.

The relationship between economic achievements and human abilities and competencies is investigated by both economists and psychologists. Chicago economists T. Schultz (1968) and G. Becker (1964) developed the concept of human capital. Schultz advanced this concept when he argued that the wellbeing of underdeveloped countries depends rather on competencies and abilities than on ground, technologies or even efforts. He defined human capital as acquired valuable qualities that can be enhanced by investing time, efforts and money. These valuable qualities bring an economic return by increasing salaries. As a result utility maximization becomes the appropriate

The investigation has been supported by the Russian Scientific Foundation, grant № 14-18-03773. 
framework to analyze human capital: investments into health, education, migration, etc. are rational - they are made for the sake of future return.

However, the power of the human capital concept goes beyond the utility maximization framework. This concept makes it possible to take into account the economic role of individual differences in human competencies and cognitive abilities.

Psychologists have the advantage of being able to directly measure cognitive abilities. They managed to find correlations between a population's mean cognitive abilities and economic achievements of regions and countries. First, Davenport and Remmers (1950) showed that per capita income in USA states correlates with the mean IQs of people called up for military service in these states. Later, Richard Lynn systematically demonstrated the same kind of correlation for regions of different nations - Great Britain, France, Spain (Lynn, 1979, 1980, 1981).

In 2002 Lynn and Vanhanen published a seminal book where they argued that national IQs are strongly associated with well-being and economic development on the international scale. The authors composed the national IQs list for 81 countries and discovered significant correlations of national IQs with per capita income and economic growth (Lynn \& Vanhanen, 2002).

Lynn and Vanhanen's book gave rise to a wave of criticism, replications and imitations but it hasn't still caused a real in-depth examination of mechanisms underlying links between cognitive abilities and economic growth.

Meanwhile, two important Lynn and Vanhanen findings deserve additional attention. First, the relationship between national IQs and income is not linear. As it was shown later this relationship can be well approximated by quadratic function (Whetzel \& McDaniel, 2006). The mere assumption that more capable, competent and educated people produce better economic results is not sufficient to explain this specific finding.

Second, residuals of the regression of GDP on national IQ grow proportionally with the IQ. It means that in some high-IQ countries human potential leads to serious economic realizations while in others it is out of demand. So a comprehensive explanation of Lynn and Vanhanen's data includes understanding of factors stimulating the use of highly qualified labor.

To understand these mechanisms we need to consider the processes that mediate human abilities and economic achievements. We propose the concept of problem solving as such a mediator. Creation of goods and services is based on problem solving in design, production and delivery. The quality of problem solving depends on human competencies and, in turn, determines economic achievements. More importantly, the choice of problems to be solved creates or does not create the possibility for application of highly qualified labor and, as a result, for full-fledged realization of human capital. In this perspective economic development depends on human capital only through mediation of problems that are solved by economic agents in a specific situation.

\section{Competences and economic problem solving}

The key assumption is that the specificity of problem mediates the economic 
return of competences. One can distinguish at least two marginal problem types. Threshold problems imply a minimum competence level that is enough for satisfactory performance (Ushakov, 2011). For instance, screwing a nut on a bolt may lead to two types of outcome: satisfactory and unsatisfactory. Being able to do it satisfactorily is enough; further competence enhancement does not result in product quality improvement.

The task of a notary officer (e.g. empowerment or drawing up of a will) requires far more skills than screwing nuts. However, as soon as the competence level is enough for processing the document correctly, its further enhancement has no impact on the resultant quality.

Therefore both aforementioned problems require a minimum competence threshold that allows for the satisfactory solution with different threshold competence levels required in different domains.

On the contrary, the open-type problem solving performance considerably varies in different specialists (Ibid.). Even the work of house painterscan differ significantly in the smoothness of paint application. Some professions have no top limits of performance. Football players, car designers, scientists or poets are valued to the extent that their performances or products shift expectations. For example, when a building design is ordered from an architectural studio, only some of the general characteristics of the building are specified, though the stature of the created design is governed by the talent and the labor of the architects and can rise to eminence in arts like the finest examples of Gaudi or Melnikov.
Thus economic agents are confronted to a number of problems and the success in solving them is related to their competence level in a complex way. These differences make the choice of problems for solving a very important economic factor.

\section{Competence and its development}

Dealing with real-life problems requires various abilities, including strength and endurance. Nonetheless the majority of economic problems have a cognitive nature, i.e. they require information processing. In other words, basic problems imply creating ideal models of objects. Actions that provide embodiment of these models, of course, are also important. Sometimes their role is crucial, e.g. in ballet or in football. In other cases it may be completely delegated to technical devices (like NC machines, for example). However, in all cases information processing and representation remain central for modern life: a reason why cognitive abilities and intelligence gain particular importance.

High intelligence level itself does not provide the entire basis for solving economic problems. Specific skills are required in particular domains like engineering, financial management, programming, et al. At the same time numerous psychological research provides evidence that competence develops on the basis of intelligence that has a partly genetic, partly environmental nature. High competence in a scientist, engineer, writer et al. can emerge only in a person with sufficient cognitive abilities.

Competence is acquired in education, in the broad meaning of the word. 
However, a person's cognitive basis helps her/him to make their own way in education and influences the final competence level. Competence acquisition occurs mainly through problem solving. While solving problems individuals learn schemes and strategies that can be generalized and transferred to other problems within the same category. A pupil solving arithmetic problems acquires methods for solving other problems, and an apprentice lathe operator turning details acquires skills necessary for turning other details.

Humanity constantly creates novel competences while new unexplored problems are being solved. Finding a solution for a novel problem opens new opportunities in two directions. First, it allows solving multistage problems where it appears as a part. For instance constructing compact and powerful batteries opens up new opportunities for creating electric cars and electronic devices. Development of the differential calculus opened the way for the development of other mathematical areas, e.g. functional analysis. Secondly, problem solving creates methods that allow the solution of problems of the same class. For example, when Claude Monet and Auguste Renoir found new ways of painting, many other artists followed it.

Novel problem domains may be far apart from the final consumption domains. A pure example comes from fundamental science where a time distance between the discovery and its practical implementation may be decades or even centuries apart. Similar distribution of functions may be observed in other domains, e.g. in art. For example, the Russian poet Vladimir Mayakovsky said about his fellow poet Velimir Khlebnikov: "A poet not for consumers, but for creators."

Often novel ways of problem solving reach the public domain, as happens in fundamental science. However, in some cases they are commercially confidential, so that corresponding competence supposedly has a commercial or other value and is transmitted only within a group membership. Gained competences of this type compose a specific capital.

There are a variety of competences required for various groups of problems. Nevertheless there is one circumstance that allows their comparison by the same scale: frequency of occurrence. Battering a nail competence is spread widely, attesting a document is much less frequent, competence in playing football like Leopoldo Messi or singing like Cecilia Bartoli is probably completely unique. It is reasonable to assume that frequency of competence at a particular level may have significant economic outcomes, i.e. be the basis for the regularities described by R. Lynn.

\section{Mechanisms for choosing and setting economic goals}

It is the entrepreneur's function to select which economic problems to solve. The entrepreneur sets goals and engages people with particular competences in order to reach these goals. The word entrepreneur is used here in the broad sense including not only business owners, but, for example, scientists who make decisions to work in one or another field of science, senior managers, etc.

A product or service resulting from highly competent problem solving may 
have stronger consumer value and therefore may be sold at higher prices. As a result we can expect market mechanisms to stimulate entrepreneurs to choose challenging problems and pay more for highly-qualified personnel. This means that market mechanisms and entrepreneurs' drive for profit may aim at the maximisation of human capital implementation.

However, in reality this mechanism's functionality is possible only under certain conditions. It is clear that these conditions include a sufficient amount of investment, the operation of necessary socio-economic institutions, etc. Additionally, two kinds of factors influence the entrepreneurs' proneness to choose challenging problems for solving. First, the entrepreneur must predict the result in terms of both usefulness and feasibility of the goods. In real life, of course, prediction may be difficult for entrepreneurs and they make mistakes. Difficulty of prediction is especially typical for the high-risk venture capital business, which, however, has particular advantages in terms of opening opportunities to address fundamentally new types of challenges. Second, the market mechanisms and entrepreneurs' drive for maximum profit may aim at choosing complex problems to solve to the extent that the profits are derived from the human labour, rather than from, for example, natural resource rent.

Based on aforementioned theoretical statements we can create a significant number of particular models to describe various aspects of the economy. Below we describe a model designed to assess to what extent the free market mechanisms can lead to the formation of relationships between the intelligence and the per capita income, as R. Lynn described them.

\section{Brief description of the simulation model}

The model considers a set of several countries and their residents. Each resident of the country has just one attribute - a talent (or professional competence) that is estimated by a number. Talents are normally distributed in each country with constant parameters. Distributions in different countries vary only in the expected (mean) values. People in each country are divided into two groups for the study: entrepreneurs and specialists. Each entrepreneur recruits specialists for producing goods. The professional competence of the specialists influences the quality of the produced goods. The goods are sold on the international product market where residents of any country can buy them. We estimate the economic achievements of each country by the sum of the income of all their entrepreneurs. In such a way we consider the influence of professional competence upon the economic results/ outcomes. The simulation model could be represented in 5 steps that are repeated constantly (see Figure 1).

As the first step each entrepreneur in every country chooses a task for solving, i.e. what to produce. The quality of produced goods (or that is the same - the successfulness of solving the problem) depends on the professional competence (that is determined by talent) of the specialists (read for more information in "Tasks and their choice" section). As the second step, every entrepreneur hires the specialists for producing the goods (for solving 
Figure 1

The scheme of the simulation model

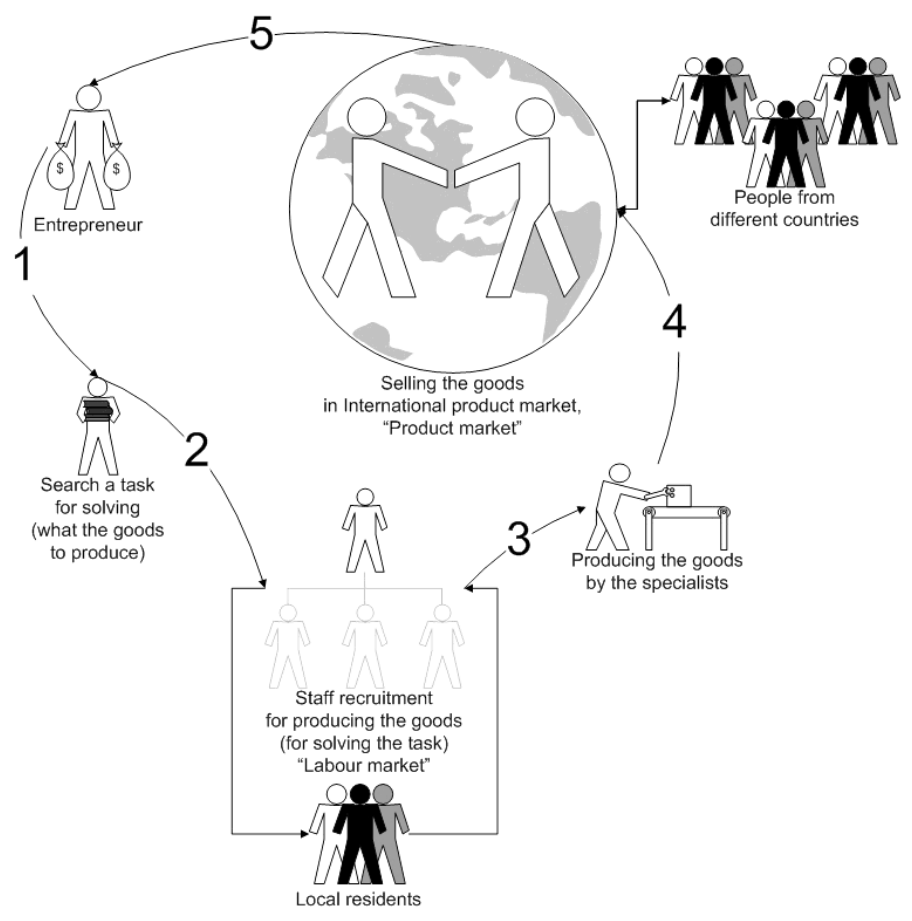

the task). The entrepreneur competes with other entrepreneurs inside his country for talented specialists by offering salaries for different positions (for more information see the section "Labor market"). As the third step, the goods are produced. The quantity of goods is determined by the number of the specialists who worked on them and by the budget that was allocated by the entrepreneur. The quality of the goods depends only on the level of competence (talents) of the hired specialists (for more information see the section "Producing the goods"). As the fourth step, every entrepreneur tries to sell their goods on the common international product market. The entrepreneur competes with entrepreneurs from all the countries for consumers through price and quality of the offered goods. We suppose that the goods of all the entrepreneurs have alternatives (for more information see the section "Product market"). As the fifth step the income that was received from selling the goods comes to the entrepreneur. The entrepreneur's budget is changed according to the production costs, paid salaries and the effects of the goods' sale. Then all the steps are repeated for all the entrepreneurs who weren't bankrupted.

We calculate GDP for a current period as the monetary value of all the goods produced by the entrepreneurs within a country and sold in the product market during that period. The countries vary in the mean values of distribution of competence levels of their local residents. 


\section{Input variables and model initialization}

During the initialization we set the vector of mean values of competence level (talent values) distribution for all the countries. A set of residents is generated for each country. In each country each resident has their own individual talent value (level of competence). The generated individual level of competence is produced according to the normal distribution with the mean value that was fixed for this country and the identical standard deviation for all the countries. The set of entrepreneurs is randomly selected from the set of residents in each country. A resident can be an entrepreneur if their level of competence is more than the mean value in this country plus one standard deviation. The rest of residents will be named specialists or consumers depending on the context. At the initial stage the amount of money of entrepreneurs and consumers is randomly distributed according to uniform distribution. Then the amount of money of an entrepreneur and a consumer is changed during next stages $1,2, \ldots, T$ according to the rules described below.

\section{Tasks and their choice}

Each entrepreneur randomly chooses a task (the task may consist in producing goods or providing services). The task consists of a finite number of subtasks of two types: open type tasks and closed type tasks, as described above.

The task (producing the goods) $k$ and its solution success $u_{k}$ are defined by the function:
Here $n$ is the number of specialists needed for solving the task $k ; x_{1}, x_{2}, \ldots, x_{n}$ are competence of specialists hired for the solving task $k ; a_{I}$ is the importance of the open type subtask $i$ for the product quality, $i=1, \ldots, r, q_{i}$ is minimal threshold for level of competence $x_{i}$ that is necessary for successful solution of closed type subtask $i, i=r+1, \ldots, n$ :

$$
\begin{aligned}
& I\left(x_{i} \geq \theta_{i}\right)=\theta_{i}, \text { if } x_{i} \geq \theta_{i} \text {, and } \\
& I\left(x_{i} \geq \theta_{i}\right)=0, \text { if } x_{i}<\theta_{i} .
\end{aligned}
$$

At the initial stage the set of all possible tasks (their parameters from (1)) is generated:

$n$ is uniform distributed over the set $\left\{1, \ldots\right.$, Const $\left._{n}\right\}$ random value;

$r$ is uniform distributed over the set $\{0, \ldots, n\}$ random value;

$a_{i},(\mathrm{i}=1, \ldots, r)$ is uniform distributed over the set $\{1,2,3\}$ random value;

$\theta_{i},(i=r+1, \ldots, n)$ is normal distributed random value, $N(70,15)$.

The vector of numbers $\left(a_{1}, a_{2}, \ldots\right.$, $\left.a_{r}, \theta_{r+1}, \theta_{r+2}, \ldots, \theta_{n}\right)$ is enough to define the function (1), therefore it fully describes the task.

The choice of the task occurs whenever it is needed according to the algorithm. The choice happens randomly according to uniform distribution over the set of all tasks.

\section{Labor market}

The algorithm of stuff recruitment is based on the assumption of higher salaries for more competitive candidates. Every entrepreneur in every country recruits specialists from this country for task solving. He proposes salary offers for all the subtasks of his

$$
u_{k}=x_{1}^{a_{1}} \cdot x_{2}^{a_{2}} \cdot \ldots \cdot x_{r}^{a_{r}} \cdot I\left(x_{r+1} \geq \theta_{r+1}\right) \cdot I\left(x_{r+2} \geq \theta_{r+2}\right) \cdot \ldots \cdot I\left(x_{n} \geq \theta_{n}\right) .
$$


task. A potential specialist chooses the position with the highest salary, where he/she is the best candidate. The algorithm sequentially enumerates (and considers) specialists from maximal level of competence to minimal and appoints the specialist to an available subtask with the highest salary. All the specialists that are appointed to the subtasks get their salary. If the entrepreneur recruits the necessary number of specialists for his task (for all subtasks) then the goods are produced with the quality uk that is defined according to (1).

The appointment "subtask - specialist" is constructed according to the algorithm:

1. Enumerate specialists descending the level of competence and subtasks descending the offered salary.

2. Choose free specialist with the minimal number. Choose free subtask with the minimal number.

3. If a current subtask is an open type subtask then we appoint a current specialist to the current subtask. If the subtask is a closed type subtask then we compare the competence level of the current specialist with a minimal threshold for the level of competence that is necessary for a successful solution of the current subtask. If the competence level of the current specialist is more than the minimal threshold then the current specialist is appointed to the current subtask. If not, then select the next available subtask according to the list (if there is an available subtask, otherwise go to point 5) and do point 3 again.

4. If there are free specialists then go to point 2 , otherwise to point 5 .

5 . End of algorithm.

\section{Producing the goods}

If the specialists have been appointed for each subtask by an entrepreneur then the goods are produced with the quantity that is calculated according to Cobb-Douglas production function (2) and with the quality determined by (1).

$$
\text { (2) } q=A \cdot K^{\alpha} \cdot L^{1-\alpha} \text {, }
$$

here $K$ is the money allocated by the entrepreneur for producing the goods (it is a 1/8 part of his budget), $L$ is the number of specialists that was appointed for the subtasks of this task, $A$ and $\alpha$ are fixed constants $(A=10, \alpha=0.5)$.

\section{Product market}

The produced goods from all countries go to the international product market. Each item of goods is determined by two attributes: $u_{k}$ is its level of quality and $q_{k}$ is its quantity. The price of each item of goods $p_{k}$ is determined according to the principle that the best quality product is bought by the richest consumers. The price $p_{k}$ of the goods $k$ is equal to the $1 / 2$ of the budget of the poorest member in the group that is ready to buy these goods. Algorithm for prices search is situated lower (see the illustration of the main principle in Figure 2).

Let us consider the algorithmic scheme of pricing the goods:

1. The goods are sorted descending the quality $u_{k}$, the consumers are sorted descending their budgets. Put the splitter that will segregate the consumers who have already bought the goods from the others before the first consumer. Set the first goods in the list as the current goods. 
The scheme of pricing in the Product market
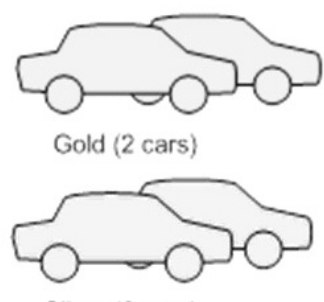

Silver (2 cars)

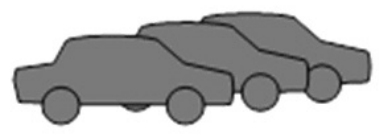

Bronze (3 cars)

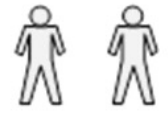

$15 \$ 10 \$$

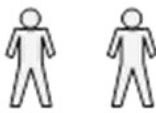

$9 \$ 7 \$$
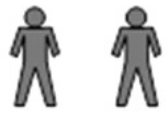

$6 \mathrm{~S}$

\section{(1)}
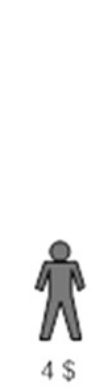

Price $7 \mathrm{~S}$

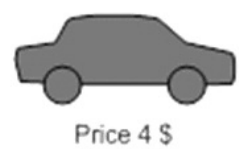

2. Move the splitter in the list of consumers down to $q_{k}$ (quantity of the current goods) steps. Set the price $p_{k}$ for the current goods as $1 / 2$ of the budget of the consumer who is over the splitter.

3. If the current item of goods is the last in the list or the splitter is under the last consumer then stop the algorithm. Otherwise, return to the point 2.

The effects of the goods' sale are added to the budget of the entrepreneur, accumulated and used over next periods. The GDP of the country is determined by the monetary value of all the goods produced by the entrepreneurs within a country and sold in the product market during the current period. Because the number of residents is the same in each country then to compare the countries on the GDP we should not divide it into the number of residents.

Then the next time period starts. At the beginning of this period an entre- preneur changes his task if it was unsuccessful during the previous period (the effect of the goods' sale was zero). Otherwise the entrepreneur keeps his prior task. The entrepreneurs set new offers of salaries for all the subtasks of their current task according to their budget. Then staff recruitment, the production and sales of the goods are repeated.

\section{Results of simulation}

Let us normalize the mean value of the competence level $I_{i}$ and the GDP $D_{i}$ in any country $i$ in order to compare the simulation results and the data from (Lynn \& Vanhanen, 2002):

$$
\begin{gathered}
I_{i}=\frac{I_{i}-\min _{k} I_{k}}{\max _{k} I_{k}-\min _{k} I_{k}}, \\
D_{i}:=\frac{D_{i}-\min _{k} D_{k}}{\max _{k} D_{k}-\min _{k} D_{k}} .
\end{gathered}
$$


Figure 3 shows both data:

- on the left empirical data from Lynn and Vanhanen (2002);

- on the right data of the simulation model.

Both empirical data and simulation have similar properties:

1. if the value $I_{i}$ grows then the mean value of $D_{i}$ grows;

2 . if the value $I_{i}$ grows then the values of quantiles $q_{1}$ and $q_{3}$ of the $9^{\text {th }}$ and $91^{\text {st }}$ percentiles and the distance between them grows, i.e. the dispersion of $D_{i}$ grows;

3 . if the value $I_{i}$ grows then the distribution of values $D_{i}$ becomes more symmetric according to its mean value.

Therefore we can conclude that the simulation reproduces most important traits of Lynn and Vanhanen's findings.

Figure 4 shows the distribution of budget size of entrepreneurs and consumers in three country groups (with

Figure 3

The values of $I_{i}$ и $D_{i}$ are obtained from (Lynn \& Vanhanen, 2002) (on the left) and from simulation model (on the right)

Data
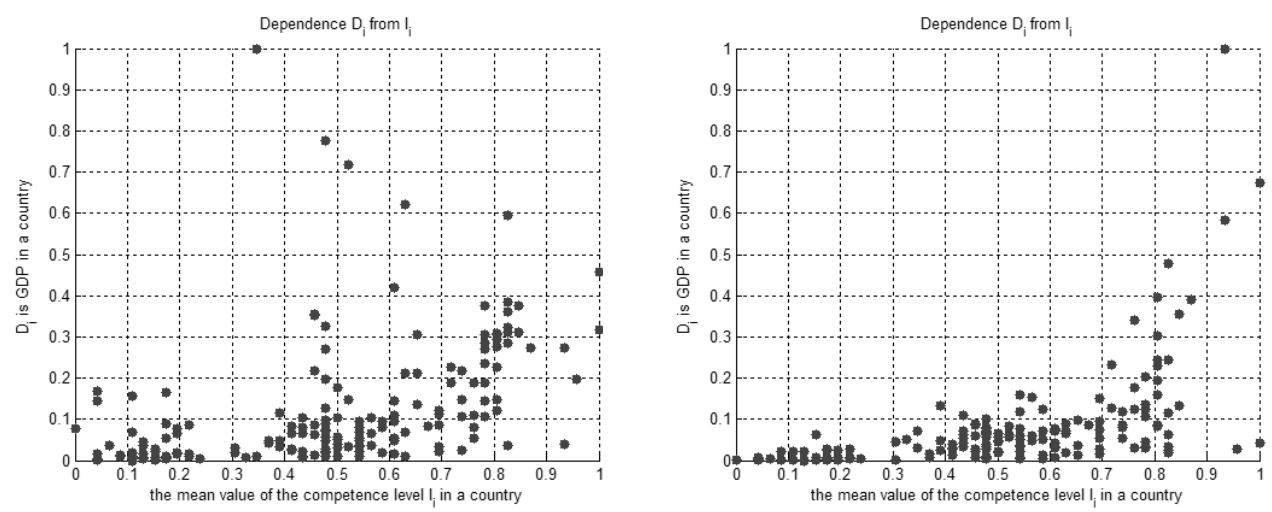

"Box plot" values $D_{i}$ in three value groups $I_{i}$
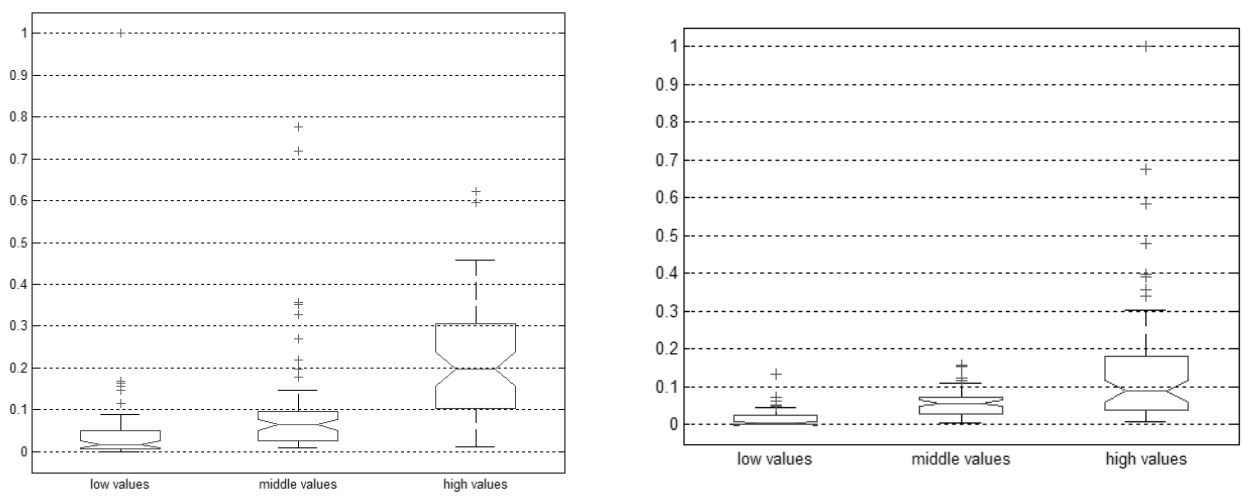
The distribution of budget size of entrepreneurs (on the right) and consumers (on the left) in countries with low, middle and high mean value of the competence level. The log-log plot is drawn (in both axes common logarithm of values are shown)

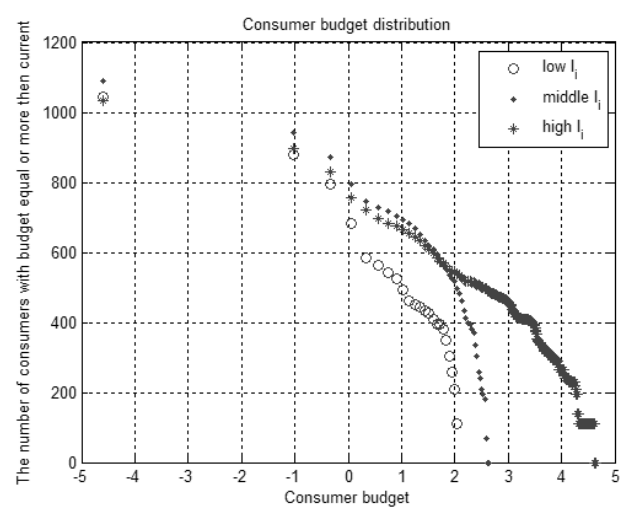

low, middle and high mean value of the competence level).

As Figure 4 shows that the dependences for entrepreneurs and consumers are similar. The rise of entrepreneurs' income influences the consumer income through salary rises. In sum, the simulation demonstrates the way through which a high cognitive level may influence a country's economic achievements.

\section{Conclusions}

In this article we have considered the simulation model where entrepreneurs choose economic tasks in a random way. After some trials unsuccessful tasks are abandoned while those that brought return are reproduced. Of course, this way is slow but after some iterations countries with more compe-

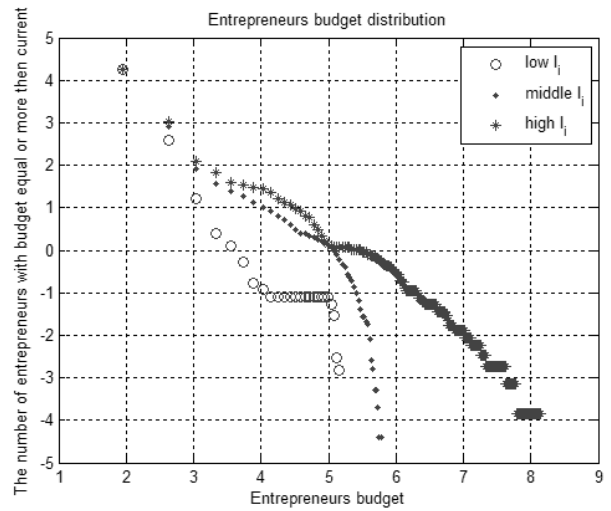

tent residents gained economic advantages. If the entrepreneurs are supposed to perfectly predict the outcome of problem solving and choose them rationally the economic advantages of more competent countries would be more shaped and less dependant on chance. In reality entrepreneurs have of course an intermediate prediction capacity differing from choosing by chance but far from being perfect. This capacity depends on cognitive abilities and competences and can be introduced in the model as one more factor influencing economic achievements.

Our model is based on the assumption that entrepreneurs' income comes from organizing people to produce goods and services. This mechanism function is impaired if natural rent becomes the main source of profit. 


\section{References}

Becker, G. S. (1964). Human capital. New York: Columbia University Press.

Davenport, K. S., \& Remmers, H. H. (1950). Factors in state characteristics related to average A-12 V-12 test scores. Journal of Educational Psychology, 41, 110-115.

Lynn, R. (1979). The social ecology of intelligence in the British Isles. British Journal of Social and Clinical Psychology, 18, 1-12.

Lynn, R. (1980). The social ecology of intelligence in France. British Journal of Social and Clinical Psychology, 19, 325-331.

Lynn, R. (1981). The social ecology of intelligence in the British Isles, France and Spain. In M. P. Friedman, J. P. Das, \& N. O'Connor (Eds.), Intelligence and learning (pp. 561-565). New York: Plenum. Lynn, R., \& Vanhanen, T. (2002). IQ and the Wealth of Nations. Westport, CT: Praeger Publishers.

Shultz, T. (1968). Human capital. In D. L. Sills (Ed.), International Encyclopedia of the Social Sciences (Vol. 6, pp. 278-286). New York: Macmillan.

Ushakov, D. V. (2011). Psikhologiya intellekta i odarennosti [Psychology of intelligence and giftedness]. Moscow: Institute of Psychology of Russian Academy of Sciences.

Whetzel, D. L., \& McDaniel, M. A. (2006). Prediction of national wealth. Intelligence, 34(5), 449-458.

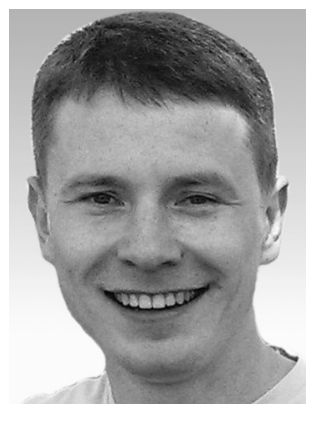

Sergei G. Kulivets - senior researcher, V. A. Trapeznikov Institute of Control Sciences of Russian Academy of Sciences, Ph.D.

Research area: game theory, cognitive maps and informational control modeling, social and complex networks, networks in cognitive Science, discrete optimization, artificial intelligence

E-mail: skulivec@yandex.ru

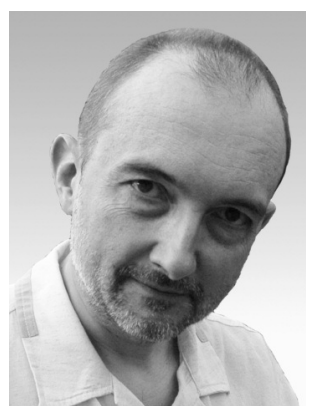

Dmitry V. Ushakov - head of the laboratory of psychology and psychophisiology of creativity, Institute of Psychology of Russian Academy of Sciences, corresponding member of Russian Academy of Sciences, D.Sc., professor.

Research area: intelligence, creativity, philosophy of psychology.

E-mail: dv.ushakov@gmail.com 


\title{
Моделирование взаимоотношений между когнитивными способностями и экономическими достижениями
}

\author{
С.Г. Куливец ${ }^{\mathrm{a}}$, Д.В. Ушаков \\ ${ }^{a}$ Институт проблем управления им. В.А. Трапезникова РАН, 117997, Россия, Москва, ул. Проф- \\ союзная, д. 65

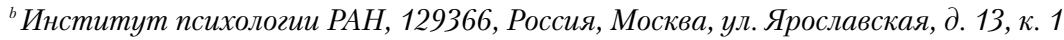

\section{Резюме}

Как экономисты, так и психологи показали большое значение когнитивных способностей и компетенций для экономических достижений. За большинством этих исследований стоит представление, что более способные и образованные люди достигают лучших результатов в экономике. Это представление, безусловно, справедливо как отражение общей тенденции, однако оно не объясняет скромные экономические достижения ряда стран с высоким уровнем развития человеческого капитала. Авторы предполагают, что связь человеческих компетенций с экономическими достижениями опосредована решением задач. Производство товаров и услуг основано на решении задач по их проектированию, изготовлению, доставке и т.д. Качество решения задач зависит от человеческих компетенций и, в свою очередь, определяет экономические достижения. Что еще более важно, выбор экономических задач для решения создает или, напротив, уничтожает возможность применения высококвалифицированного труда и, следовательно, достаточно полной реализации человеческого капитала в экономических достижениях. В статье предлагается математическая модель, основанная на указанных предпосылках. Результаты, сгенерированные с помощью этой модели, воспроизводят основные данные Р. Линна и Т. Ванханена (2002). Так, модель показывает нелинейное возрастание экономических достижений с повышением среднего интеллекта стран, а также параллельное возрастание дисперсии между различными странами. Таким образом, можно заключить, что предложенная модель удовлетворительно объясняет эмпирические данные о связи интеллекта с экономическими достижениями.

Ключевые слова: интеллект, компетенции, человеческий капитал, ВВП, решение задач.

Куливец Сергей Геннадьевич - научный сотрудник, Институт проблем управления им. В.А. Трапезникова РАН, кандидат технических наук.

Сфера интересов: теория игр, когнитивные карты и информационное управление, анализ больших сетей, дискретная оптимизация, искусственный интеллект.

Контакты: skulivec@yandex.ru

Ушаков Дмитрий Викторович - заведующий лабораторией, ФГБУН Институт психологии РАН, член-корреспондент РАН, доктор психологических наук, профессор. Сфера научных интересов: интеллект, креативность, методология психологии. Контакты: dv.ushakov@gmail.com 